\title{
Peningkatan Pengetahuan Kader Posyandu dalam Penggunaan Buku KIA
}

\author{
Eli Rahmawati ${ }^{\star}$, Ernani Setyawati, Novia Nurhasanah \\ Jurusan Kebidanan, Poltekkes Kemenkes Kalimantan Timur \\ *Email korespondensi: el.rahmahadi@gmail.com
}

\begin{abstract}
History Artikel
Received: 16-06-2020

Accepted: 01-08-2020

Published: 22-08-2020

Kata kunci:

Pengetahuan; Kader

Posyandu; Buku KIA

\section{ABSTRAK}

Upaya percepatan menurunkan AKI dan AKB dilakukan melalui beberapa kegiatan terobosan dalam sector kesehatan, diantaranya: Program Perencanaan Persalinan dan Pencegahan Komplikasi (P4K), kemitraan bidan dukun, pemanfaatan Buku KIA dan revitalisasi Pemantauan Wilayah Setempat Kesehatan Ibu Anak (PWS KIA). Kegiatan Posyandu dalam pelaksanaanya sangat memerlukan peran penting kader. Namun jumlah kader yang pengetahuannya (pemahaman \& ketrampilan) kurang dalam mendukung pelaksanaan tugasnya masih banyak. Tujuan pengabdian masyarakat adalah untuk mengetahui Karakteristik Kader posyandu yang hadir dalam kegiatan (Usia, Tingkat Pendidikan dan lama menjadi kader), Peningkatan Pengetahuan Kader Posyandu dalam menggunaan Buku KIA. Metode yang digunakan adalah ceramah dan diskusi. Jumlah peserta sebanyak 120 orang. Hasil yang diperoleh karakteristik peserta kegiatan pengabdian masyarakat adalah sebagai berikut: usia peserta berada antara range 27 sampai dengan 63 tahun, lama bertugas sebagai kader antara range 2- 32 tahun dan tingkat Pendidikan antara SMP sampai dengan Sarjana. Rerata nilai pretest adalah 48,57 dan rerata nilai post test adalah 64,89 . Terjadi peningkatan nilai rerata skor sebanyak 16, 33, sehingga dapat disimpulkan bahwa pemberian pengetahuan dapat meningkatkan pengetahuan kader posyandu dalam penggunaan Buku KIA.
\end{abstract}

Keywords:

Knowledge;

Posyandu Cadre;

KIA Book

\begin{abstract}
In an attempt to accelerate the decline of $A K I$ and $A K B$, the health sector made a breakthrough using the Program Perencanaan Persalinan dan Pencegahan Komplikasi (P4K), midwife medicaster relations, the utilization of $\mathrm{MCH}$, and the practical revitalization of Pemantauan Wilayah Setempat Kesehatan Ibu Anak (PWS KIA). The role of health service workers in the practice of Integrated Service Posts are crucial. Alas, a huge number of health service workers have the lack of comprehension and skills in regards of doing their tasks. The purpose of social service is to identify the characteristics of the Integrated Health Service workers that take parts in social service (i.e. Age, Education Level, and their tenure as health services workers). Efforts regarding the development of the service workers' comprehension of KIA books, and the effectiveness of $\mathrm{MCH}$ books towards society, particularly health service workers. The methods used are lectures and discussions. As 120 participant. The results gained from the participants are as follows: Ages in the range of 27-63 years, Tenures in the range of 2-32 years, and Education Levels in the range of Junior high-university graduates. The numerical mean for pretest is 48.57 and for post test is 64.89. An increased number of mean had been achieved by 16.33. This result concludes that education may develop the comprehension of health service workers in the utilization of $\mathrm{MCH}$ book.
\end{abstract}




\section{PENDAHULUAN}

Keberhasilan Pembangunan sektor kesehatan indikator keberhasilannya ditentukan berdasarkan Angka Kematian lbu (AKI) dan Angka Kematian Bayi (AKB). Hal ini juga menggambarkan kualitas ibu dan anak di Indonesia. Tingginya AKI yaitu sebesar 305/100.00 Kelahiran Hidup (KH) dan AKB 22,23/100 KH termasuk tantangan paling berat untuk mencapai Sustainable Development Goal's (SDG,S) pada tahun 2030 (Badan Pusat Statistik, 2016). Terobosan percepatan penurunan AKI dan AKB dari sektor kesehatan diupayakan melalui Program Perencanaan Persalinan dan Pencegahan Komplikasi (P4K), kemitraan bidan dan dukun, pemanfaatan Buku KIA serta merevitalisasi pelaksanaan Pemantauan Wilayah Setempat Kesehatan Ibu Anak (PWS KIA). Peningkatan akses masyarakat terhadap pelayanan kesehatan ibu, meningkatnya keterlibatan dan peran serta keluarga, kader, masyarakat serta petugas kesehatan dalam memandirikan masyarakat untuk membuat perencanaan persalinan serta mengetahui tanda bahaya pada kehamilan, persalinan dan nifas serta memanfaatkan Buku Kesehatan lbu dan Anak diharapkan terjadi (Kementerian Kesehatan R.I., 2015).

Keputusan Menteri Kesehatan Republik Indonesia 284/MENKES/SK/III/2004 tentang Buku KIA bahwa alat untuk mendeteksi secara dini adanya gangguan atau masalah kesehatan ibu dan anak, alat komunikasi dan penyuluhan dengan informasi yang penting bagi ibu dan keluarga dan masyarakat mengenai pelayanan kesehatan ibu dan anak termasuk rujukannya dan paket (standar) pelayanan KIA, gizi, imunisasi dan tumbuh kembang balita (Kementerian Kesehatan R.I., 2015).

Hasil Survei Indikator Kesehatan Nasional tahun 2016 terkait dengan data yang berhubungan dengan Buku KIA dilaporkan sebagai berikut: kepemilikan buku KIA pada ibu mencapai $91.5 \%$, kepemilikan pada anak $46.4 \%$, tidak memiliki buku KIA $18.40 \%$, memiliki dan bisa menunjukkan Buku KIA 60.50\%, implementasi pemanfaatan Buku KIA bervariasi di daerah, kepatuhan petugas dan masyarakat masih perlu ditingkatkan, hasil analisis kepemilikan Buku KIA dapat meningkatkan kemungkinan ibu untuk bersalin di tenaga kesehatan, kepemilikan Buku KIA dapat meningkatkan kemungkinan Balita melakukan penimbangan/ pemantauan pertumbuhan serta kepemilikan Buku KIA memiliki korelasi positif terhadap Imunisasi Dasar Lengkap (IDL), kunjungan Neonatal (KN1) dan penimbangan Balita (Kementerian Kesehatan R.I., 2017).

Di Kota Balikpapan Angka Kematian Ibu mengalami penurunan. Tahun 2015 jumlah kasus 9 atau 72/100.000 $\mathrm{KH}$ dengan perhitungan jumlah kelahiran di Balikpapan adalah 12.421. Target penurunan AKI secara Nasional yaitu 112/100.000 $\mathrm{KH}$. Dengan demikian penurunan AKI kota Balikpapan dari 124/100.000 KH tahun 2014 menjadi 72/100.000 KH tahun 2015, pencatatan dan pelaporan kematian ibu yang semakin baik sebagai faktor penunjangnya (Dinas Kesehatan Kota Balikpapan, 2015). Beberapa upaya telah dilakukan untuk menurunkan AKI ini terbitnya Perda KIBLA nomor 9 tahun 2015, penguatan penggunaan buku KIA, kegiatan Audit Maternal Perinatal, meningkatkan koordinasi Program Maternal Provinsi Kalimantan Timur, terbentuknya Tim Maternal Perinatal kota, penguatan SDM Puskesmas PONED, meningkatkan program kemitraan dengan Organisasi Profesi, Akademisi Kebidanan, PKK, swasta, Lintas Sektor terkait, membuka jaringan komunikasi online, melakukan akselerasi kegiatan promosi preventif kesehatan kunjungan rumah ibu hamil, ibu nifas dan Bantuan Operasional Kesehatan (BOK) dari Kemenkes RI dan dikembangkannya program Sistem Informasi Kegiatan Maternal Perinatal rujukan on line bekerja sama dengan Universitas Gadjah Mada (Peraturan Daerah (PERDA) No.9 Tahun 2015 Tentang Kesehatan Ibu Dan Anak, 2015). 
Dalam Proyek Perubahan yang merupakan kegiatan yang dilaksanakan dalam kepesertaan Diklat PIM IV, dilaporkan bahwa telah dihasilkan kuisoner ibu hamil, ibu nifas, dan petugas kesehatan yang valid untuk mengukur tingkat pemahaman ibu tentang isi buku KIA dan kepatuhan tenaga kesehatan dalam memberikan KIE dan mengisi buku KIA, ditemukan gambaran hasil survey masih ada ibu hamil/ibu nifas yang masih belum paham beberapa poin dalam buku KIA dan masih diperlukannya komitmen petugas kesehatan dan kader dalam memberi KIE dan mengisi buku KIA (Aspar, 2015).

Di Indonesia buku KIA kurang di manfaatkan secara optimal, terbukti dengan rendahnya kesadaran ibu untuk membaca pesan yang terdapat dalam buku KIA. Didukung penelitian yang dilakukan Sistiarani et al (2014), melaporkan ibu yang memiliki pengetahuan baik tentang buku KIA akan meningkatkan kepatuhan penggunaan buku KIA (p: 0,027). Kader berpengaruh terhadap pemanfaatan buku KIA (OR: 6,63 p: 0,032) (Sistiarani et al., 2014). Wijhati et al (2017) melaporkan hasil penelitiannya tentang hubungan antara peran kader dengan pemanfaatan buku KIA. Didapatkan hasil bahwa Kader yang berperan baik meningkatkan kemungkinan pemanfaatan buku KIA sebanyak 1,6 kali lebih besar (Wijhati et al., 2017).

Jumlah total Posyandu yang tersebar di seluruh wilayah Indonesia adalah sebanyak 283.370, dan posyandu yang aktif 173.750 atau sebanyak $61,32 \%$ (Kementerian Kesehatan R.I., 2019). Di Kalimantan Timur jumlah total Posyandu adalah 4.348 dan sebanyak $42,76 \%$ diantaranya merupakan posyandu yang aktif. Menurut Tse, et al, (2017) dalam pelaksanaan kegiatan Posyandu peran kader sangat penting (Tse et al., 2017). Peran serta masyarakat dalam pembangunan kesehatan merupakan perwujudan nyata dari kader sebagai mitra kesehatan yang berasal dari masyarakat. Tingginya peran kader terlihat dari tingkat aktivitas dan sasaran programnya. Namun sebagai pengelola posyandu ternyata masih banyak kader yang belum memiliki pemahaman dan keterampilan yang memadai dalam melaksanakan tugasnya yang idealnya kader diharapkan paling memahami kondisi kebutuhan masyarakat di wilayahnya (Kementerian Kesehatan R.I. \& Pokjanal Posyandu Pusat, 2012)

Hasil penelitian yang berkorelasi positif tentang pengetahuan kader dan kegiatan posyandu telah banyak dilakukan. Handika, dkk (2016) melaporkan ada hubungan tingkat pengetahuan dengan keaktifan kader dalam menjalankan posyandu, Profita (2018) meneliti tentang faktor yang berhubungan dengan keaktifan kader posyandu dengan hasil pengetahuan, motivasi dan dukungan merupakan factor yang berhubungan dengan keaktifan kader posyandu. Diperkuat oleh penelitian Juliati (2019) yang menyatakan bahwa salah satu hambatan yang dimiliki kader adalah kurangnya pengetahuan tentang posyandu karena minimnya pelatihan. (Handika, 2016; Juliati et al., 2019; Profita, 2018)

Data riil jumlah kader posyandu yang ada di Balikpapan sebanyak 5.097 orang. Dilaporkan sebanyak 92,78\% kader aktif di kota Balikpapan dan 7,22\%. Kader yang tidak aktif. Kecamatan Balikpapan Utara memiliki angka keaktifan kader tertinggi yaitu sebesar 99,71\% (Dinas Kesehatan Kota Balikpapan, 2017). Berdasarkan latar belakang tersebut maka terdapat ketertarikan untuk melakukan pengabdian masyarakat guna meningkatkan pengetahuan kader posyandu dalam penggunaan Buku KIA di Kota Balikpapan tahun 2019.

Tujuan Kegiatan adalah diketahuinya Karakteristik Kader posyandu yang hadir dalam kegiatan pengabdian masyarakat (Usia, Tingkat Pendidikan dan lama menjadi kader) dan Meningkatnya Pengetahuan Kader Posyandu dalam Penggunaan Buku $\mathrm{KIA}$. 


\section{METODE PELAKSANAAN}

Tempat dan Waktu Kegiatan pengabdian masyarakat dilaksanakan pada tanggal 21 Agustus 2019, bertempat di Hotel Pacific Balikpapan bekerjasama dengan Dinas Kesehatan Kota Balikpapan

Khalayak Sasaran. Sasaran dari pengabdian masyarakat adalah perwakilan kader posyandu dari tiap Kecamatan di Kota Balikpapan yang berjumlah 200 kader namun yang dapat menghadiri kegiatan ini sebanyak 120 orang.

Metode Pengabdian. Metodologi yang digunakan dalam kegiatan pengabdian masyarakat adalah sebagai berikut: a). Pengumpulan data kader yang bersumber melalui informasi yang didapat dari Dinas Kesehatan Kota Balikpapan. b). Peningkatan pengetahuan kader dilakukan melalui pemberian pengetahuan (ceramah \& diskusi) dalam bentuk penyegaran materi tentang Buku KIA meliputi: definisi, komponen, manfaat, dan penggunaan serta bagian dari Buu KIA yang dapat diisi oleh kader, dan c). Evaluasi Kegiatan dilakukan melaui kegiatan pretest dan posttest tentang pengetahuan buku KIA, meliputi: definisi, komponen, manfaat, sasaran dan cara penggunaan buku KIA.

Metode Evaluasi. Evaluasi dilakukan dengan membandingkan nilai hasil pretest dan posttest.

\section{HASIL DAN PEMBAHASAN}

\section{A. Hasil}

Kegiatan pengabdian masyarakat yang dilaksanakan pada tanggal 21 Agustus 2019 yang dilaksanakan dari pukul 08.00 s.d 12.00 WITA, bekerjasama dengan Dinas Kesehatan Kota Balikpapan. Kegiatan yang dihadiri oleh Kabid. Kesehatan Masyarakat DKK Balikpapan dr. Sriyono dan staff dilaksanakan dengan tujuan untuk meningkatkan pengetahuan kader posyandu dalam penggunaan buku KIA. Dihadiri oleh kader sebanyak 120 dari 200 sasaran yang direncanakan.

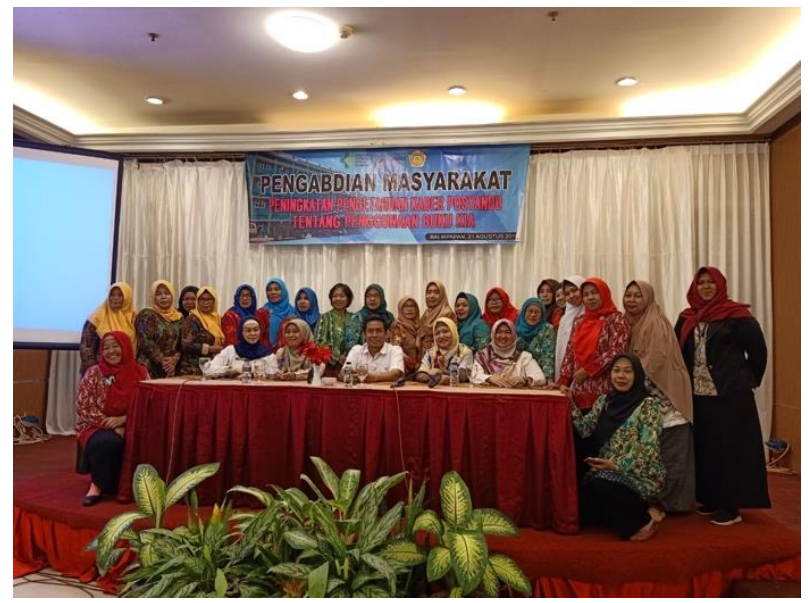

Gambar 1. Foto Bersama Kepala Bidang Kesehatan Masyarakat, Kasie Kesehatan Keluarga , Kasie Gizi dan Kesjaor dan staff dan Kader peserta pengabdian masyarakat.

Kegiatan diawali dengan pemberian pretest. Skor terendah hasil pretest adalah 20 dan tertinggi 90 . Selanjutnya dilakukan pemberian pengetahuan dengan metode ceramah tentang penggunaan buku KIA kepada kader posyandu selama 50 menit dan dilanjutkan dengan sesi diskusi. Materi pengetahuan meliputi: 1) pentingnya 
penggunaan Buku KIA, 2) Komponen yang terdapat dalam buku KIA, 3) manfaat buku KIA dan 4) cara penggunaan Buku KIA.

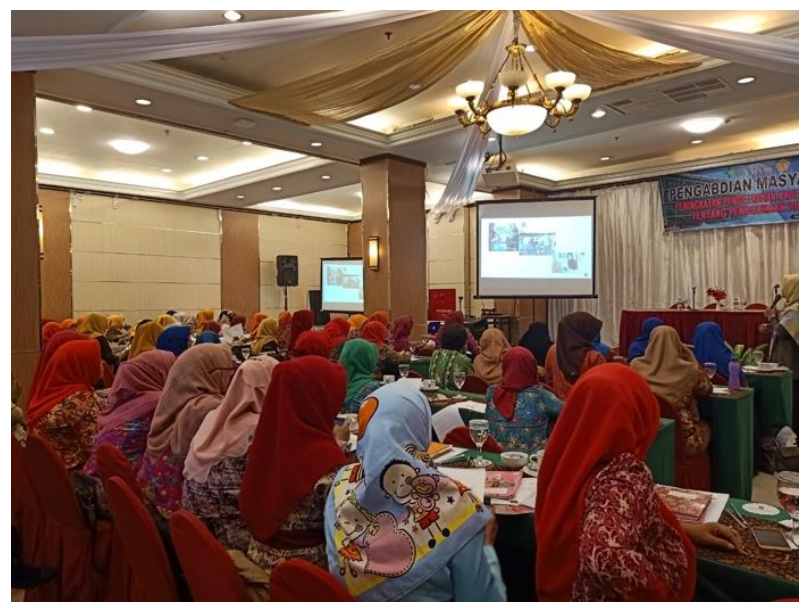

Gambar 2. Pemberian Materi pengabdian masyarakat.

Setelah kegiatan pemberian pengetahuan dilakukan kembali penilaian posttest dengan capaian nilai skor terendah adalah 30 dan skor tertinggi 90 . Rata-rata nilai pretest adalah 48,57 dan nilai posttest rerata adalah 64,89 . Terjadi peningkatan nilai rerata skor sebanyak 16, 33 .

Hasil Karakteristik peserta kegiatan pengabdian masyarakat (usia, tingkat Pendidikan \& lama bertugas menjadi kader) adalah sebagai berikut: usia peserta berada antara range 27 s.d 63 tahun, lama bertugas sebagai kader antara range 2 s.d 32 tahun dan tingkat Pendidikan antara SMP s.d Sarjana. Untuk lebih jelasnya dapat dilihat pada table dibawah ini

Tabel Karakteristik Kader Posyandu $n=120$

\begin{tabular}{ccc}
\hline & Jumlah & Persen \\
\hline Usia & 34 & 28.3 \\
20-40 tahun & 84 & 70 \\
$41-60$ ahun & 2 & 1.67 \\
$>$ 60 tahun & & \\
Tingkat Pendidikan & 26 & 21.67 \\
SMP & 85 & 70.83 \\
SMA & 9 & 7.5 \\
D3-S1 & & \\
Lamanya menjadi & 53 & 44.17 \\
kader & 61 & 60.83 \\
$<5$ tahun & 6 & 5 \\
6-20 tahun & 120 & 100 \\
$>$ 20 tahun & & \\
\hline Jumlah & & \\
\hline
\end{tabular}




\section{B. Pembahasan}

Kegiatan pengabdian masyarakat ini dilakukan dengan tujuan meningkatkan pengetahuan kader posyandu dalam menggunakan buku KIA. Kegiatan ini dapat terlaksana berkat kerjasama dengan Dinas Kesehatan Kota Balikpapan dalam kegiatan penyegaran kader yang merupakan agenda yang dilakukan secara rutin oleh DKK kota Balikpapan. Dari 200 sasaran yang direncanakan berhasil hadir dalam kegiatan sebanyak 120 peserta. Tujuan kegiatan penyegaran kader posyandu dilakukan untuk meningkatkan pengetahuan kader dalam memberikan pelayanan kesehatan di masyarakat. Menurut Notoatmojo (2010) Perubahan perilaku dan norma kesehatan dapat dicapai melalui pendidikan kesehatan (Notoatmodjo, 2010). Dari hasil penilaian pre-test dan post-test diketahui bahwa terjadi peningkatan persentase pengetahuan kader yang terlihat dari rerata kenaikan skor sebanyak 16,33 poin. Krisnana et al (2017) berpendapat bahwa kader sebagai pemberi informasi kesehatan sebaiknya memiliki pengetahuan dan pemahaman materi yang baik (Krisnana et al., 2017). Kader yang memiliki pengetahuan berhubungan pula dengan keaktifan kader dalam menyelenggarakan kegiatan posyandu (Profita, 2018). Hal serupa dikemukakan oleh Purnomo \& Suratini (2014), bahwa pengaruh signifikant terjadi saat kader diberi materi pelatihan tentang pengelolaan posyandu, mengingat kader kesehatan memiliki peran penting dalam penyelenggaraan kegiatan di posyandu (Purnomo \& Suratini, 2014).

Pencatatan buku KIA di Posyandu yang dilakukan bidan desa dapat dibantu oleh kader (Kementerian Kesehatan R.I., 2015). Masyarakat dapat dengan mudah memperoleh pelayanan kesehatan dasar di posyandu sehinga AKI dan AKB dapat cepat menurun. Pelayanan KIA sebagai kegiatan utama posyandu meliputi pelayanan ibu hamil (timbang berat badan, ukur tinggi badan, ukur tekanan darah dan gizi), pelayanan gizi dan pencegahan diare (Kementerian Kesehatan R.I. \& Pokjanal Posyandu Pusat, 2012).

Buku KIA merupakan bagian yang tidak terpisahkan dalam kegiatan posyandu, buku KIA merupakan catatan terpadu keluarga untuk meningkatkan paktek keluarga dan masyarakat dalam pemeliharaan kesehatan ibu dan anak sehingga kualitas pelayanan KIA dapat meningkat. Penelitian yang dilakukan oleh Ainiyah, (2017) tentang penggunaan buku KIA terhadap ibu hamil dan anak terbukti dapat meningkatkan perilaku kesehatan ibu hamil trimester III (Ainiyah et al., 2018).

Karakteristik usia peserta berada dalam kisaran 27 tahun sampai dengan 63 tahun. Perubahan perilaku terjadi pada kelompok usia muda dibandingkan usia tua karena lebih mudah menerima informasi. Pengalaman yang diperoleh oleh kader usia tua dijadikan sebagai informasi sehingga memiliki pengetahuan dan ketrampilan yang lebih baik dalam menggunakan buku KIA (Sukandar et al., 2018).

Lamanya kader bertugas dari data yang diperoleh berada dalam rentang 2 tahun sebagai kader paling baru dan masa terlama adalah 32 tahun sebagai kader. Ketrampilan kerja yang lebih dapat terlihat dari lama kerja. Dengan pengalaman dan ketrampilan yang dialami dalam jangka waktu lama sebagai kader diharapkan semakin baik ketrampilan kader dalam menggunakan buku KIA (Fardila \& Risma, 2019). Tingkat Pendidikan Kader yang hadir sebagai peserta memiliki rentang dari SMP hingga level Sarjana. Sebagian besar Kader yang hadir (70, 83\%) memiliki Pendidikan terakhir SMA dan hanya sebagian kecil yang berpendidikan SMP $(21,67 \%)$ dan Perguruan Tinggi $(7,5 \%)$. Namun berbeda dengan penelitian Sukandar, DKK (2019) bahwa tidak ada hubungannya usia, tingkat pendidikan dan 
lama menjadi kader terhadap tingkat akivitas kader. Menurut Profita (2018) pengetahuan, motivasi, dan dukungan dari berbagai pihaklah yang dibutuhkan oleh kader agar kader aktif di posyandu.

\section{SIMPULAN}

Karakteristik peserta kegiatan pengabdian masyarakat adalah usia peserta berada antara range 27-63 tahun, lama bertugas sebagai kader antara range 2- 32 tahun dan tingkat Pendidikan antara SMP-Sarjana. Rerata nilai pretest adalah 48,57 dan rerata nilai post test adalah 64,89 . Terjadi peningkatan nilai rerata skor sebanyak 16,33 sehingga dapat disimpulkan bahwa pemberian pengetahuan dapat meningkatkan pengetahuan kader pos yandu dalam penggunaan Buku KIA

Peningkatan pengetahuan diharapkan berdampak terhadap penggunaan Buku KIA oleh kader posyandu di masyarakat dan pemberian pengetahuan idealnya ditindaklanjuti dengan pemberian ketrampilan agar peningkatan pengetahuan kader posyandu tentang buku KIA dapat tercapai dan terevaluasi lebih baik.

\section{DAFTAR PUSTAKA}

Ainiyah, N. H., Hakimi, M., \& Anjarwati, A. (2018). The use of Maternal and Child Health (MCH) handbook improves healthy behavior of pregnant women. Majalah Obstetri \& Ginekologi, 25(2), 59. https://doi.org/10.20473/mog.V25122017.59-62

Aspar, P. (2015). Proyek Perubahan. Laporan Diklat PIM IV.

Badan Pusat Statistik. (2016). Profil Penduduk Indonesia Hasil Supas 2015. Badan Pusat Statistik.

Dinas Kesehatan Kota Balikpapan. (2015). Profil Kesehatan Tahun 2015.

Dinas Kesehatan Kota Balikpapan. (2017). Profil Kesehatan kota Balikpapan 2017.

Fardila, E., \& Risma, R. (2019). Hubungan Pelatihan Keterampilan Dengan Pengetahuan Kader Tentang Peran Fungsi Sistem 5 Meja Di Posyandu Wilayah Kerja Puskesmas Jatinangor Kabupaten Sumedang Tahun 2018. Jurnal Sehat Masada, XIII(1), 65-73.

Handika, F. F. (2016). Hubungan Tingkat Pengetahuan Dengan Keaktifan Kader Dalam Menjalankan Posyandu Balita Di Desa Pacalan Wilayah Kerja Puskesmas Plaosan [Universitas Muhammadiyah Surakarta]. http://eprints.ums.ac.id/41750/

Juliati, Badiran, M., \& Ain, N. (2019). Peran Kader dalam Pelaksanaan Kegiatan Posyandu di Dusun Titipanjang Wilayah Kerja Puskesmas Bunut Kab. Labuhan Batu Selatan. Jurnal Mutiara Kesehatan Masyarakat., 4(2), 72-80. http://e-journal.sarimutiara.ac.id/index.php/JMKM/article/view/880

Kementerian Kesehatan R.I. (2015). Petunjuk Teknis Penggunaan Buku Kesehatan Ibu dan Anak. Kementerian Kesehatan R.I. http://kesga.kemkes.go.id/images/pedoman/JUKNIS BUKU KIA 2016.pdf

Kementerian Kesehatan R.I. (2017). Laporan Survei Indikator Kesehatan Nasional 2016.

Kementerian Kesehatan R.I. (2019). Profil Kesehatan Indonesia 2018. Kementerian Kesehatan R.I.

Kementerian Kesehatan R.I., \& Pokjanal Posyandu Pusat. (2012). Kurikulum dan Modul Pelatihan Kader Posyandu. Kementerian Kesehatan R.I.

Krisnana, I., Rachmawati, P. D., \& Airlangga, U. (2017). Peningkatan Pengetahuan Kader Posyandu tentang PMT Dalam Upaya Pencegahan Gizi Buruk pada Balita. Pediomaternal Nursing Journal, 4(1-5). https://publikasi.unitri.ac.id/index.php/fisip/article/view/372/305

Notoatmodjo, S. (2010). IImu Perilaku Kesehatan. Rineka Cipta.

Peraturan Daerah (PERDA) No.9 Tahun 2015 tentang Kesehatan Ibu dan Anak, (2015).

Profita, A. C. (2018). Beberapa Faktor yang Berhubungan dengan Keaktifan Kader Posyandu di Desa Pengadegan Kab. Banyumas. Jurnal Administrasi Kesehatan Indonesia, 6(2), 68. https://doi.org/10.20473/jaki.v6i2.2018.68-74

Purnomo, G. A., \& Suratini, S. (2014). Pengaruh Pelatihan Kader tentang Posyandu Terhadap Kemampuan Pengelolaan Posyandu di Desa Sendangsari Kecamatan Pengasih Kulon 
Progo. STIKES 'Aisyiyah Yogyakarta.

Sistiarani, C., Gamelia, E., \& Hariyadi, B. (2014). Analisis Kualitas Penggunaan Buku Kesehatan Ibu Anak. KESMAS - Jurnal Kesehatan Masyarakat, 10(1), 14-20. https://doi.org/10.15294/kemas.v10i1.3065

Sukandar, H., Faiqoh, R., \& Effendi, J. S. (2018). Hubungan Karakteristik terhadap Tingkat Aktivitas Kader Posyandu Kecamatan Soreang Kabupaten Bandung. Jurnal Sistem Kesehatan, 4(38), 102-109.

Tse, A. D. P., Suprojo, A., \& Adiwidjaja, I. (2017). Peran Kader Posyandu Terhadap Pembangunan Kesehatan Masyarakat. Jurnal IImu Sosial Dan IImu Politik Universitas Tribhuwana Tunggadewi, 6(1), https://publikasi.unitri.ac.id/index.php/fisip/article/view/372/305

Wijhati, E., Suryantoro, P., \& Rokhanawati, D. (2017). Optimalisasi Peran Kader dalam Pemanfaatan Buku KIA di Puskesmas Tegalrejo Kota Yogyakarta. Jurnal Kebidanan, 6(2), 112. https://doi.org/10.26714/jk.6.2.2017.112-119 